Article

\title{
Rootstock Effects on Yield and Some Consumer Important Fruit Quality Parameters of Eggplant cv. 'Madonna' under Protected Cultivation
}

\author{
Maryam Mozafarian ${ }^{\circledR}$, Nazatul Syaima Binti Ismail and Noémi Kappel *(i) \\ Department of Vegetable and Mushroom Growing, Faculty of Horticultural Science, Szent István University, \\ Villányi út 29-43, H-1118 Budapest, Hungary; maryammozafariyan67@gmail.com (M.M.); \\ syaima.unibio@gmail.com (N.S.B.I.) \\ * Correspondence: Kappel.Noemi@szie.hu; Tel.: +36-30-215-8922
}

Received: 14 August 2020; Accepted: 20 September 2020; Published: 22 September 2020

\begin{abstract}
This study aimed to investigate the effect of different rootstocks on the yield and quality of eggplant cv. 'Madonna' in soilless pot culture in an unheated polyethylene greenhouse. The eggplant was grafted onto several rootstocks, including tomato rootstocks Optifort (O) and Emperador $(\mathrm{E})$, and four Solanum rootstocks; Solanum grandiflorum $\times$ Solanum melongena $(\mathrm{SH})$, Solanum toroum (ST), Solanum melongena $\times$ Solanum integrifolium (SI), and Solanum integrifolium (A) compared with self-grafted (SG) and self-rooted (SR) as control. The results showed that the total marketable yield significantly increased by grafting onto ST (3.94 kg/plant), SH (3.36 kg/plant), and A (3.34 kg/plant) relative to SR (1.65 kg/plant). The chromatics characters of skin and pulp are slightly influenced by rootstocks. Our findings confirmed that grafting eggplant decreased firmness (except SH) of the flesh. Fruit harvested from the Optifort/Madonna combination had the rounded shape, lowest firmness, and Brix value, while the lowest oxidation potential was observed in this combination. The highest seed number was observed in SH/Madonna and SI/Madonna combinations. During the sensory evaluation, the lightest fruit flesh was found in SR, ST, and O, and the sweetest taste was observed in fruits harvested from ST rootstock.
\end{abstract}

Keywords: eggplant grafting; rootstock; fruit quality; yield; sensory evaluation

\section{Introduction}

The eggplant (Solanum melongena $\mathrm{L}$.) is one of the top ten vegetables that originated from Southeast Asia; it has a high antioxidant capability and nutrient value. Soil-borne diseases, and biotic and abiotic stresses have limited the yield in many commercial eggplant plantations. Vegetable grafting is considered to be a rapid alternative way to slow breeding due to the absence of resistance genotype [1]. Grafting has been found effective not only for resistance advantages but also for the improvement of production and some quality traits of the fruit [2,3]. Eggplant grafting was started in the early 1950s by using Scarlet eggplant as rootstocks [4].

Several studies have already investigated different eggplant scion-rootstock combinations [5-8]. For instance, Solanum paniculatum increased vigour and fruit yield, but did not have any positive effect on fruit quality and composition [6]. Solanum incanum induced tolerance to water and temperature stress [9], while Solanum aethiopicum and Solanum macrocarpon were tolerant to Fusarium oxysporum and resistant to Ralstonia solanacearum [10]. Solanum sisymbriifolium and Solanum integrifolium have been reported effective in controlling bacterial wilt and resulted in higher yield [11]. Solanum torvum is the most commonly used rootstock for eggplant, which has been reported to be resistant to soil-borne diseases; but due to lack of rapid and homogeneous seed germination, there is a need to 
find other alternative rootstocks [12]. Some tomato rootstocks can be valuable, as well, to improve eggplant growth and production. Grafting eggplant onto tomato rootstocks (Solanum lycopersicum L. $\times$ Solanum habrochaites) indicated a positive result on yield and the appearance of fruits, but not equally, and it largely depended on the combination and environment [13]. Overall, some rootstock-scion combinations are moderately compatible, and unfavourable effects may occur; hence, the selection of appropriate rootstock-scion combinations is crucial.

Fruit quality of grafted vegetables can be measured by sensory evaluation and instrumental methods as well [14]. Grieneisen et al. [15] conducted a review of 202 different rootstocks and 1023 experimental treatments related to tomato grafting, and they concluded that fruit quality data based on sensory tests were rare among the published studies. Sensory evaluation of grafted plants of the members of the Cucurbitaceae family, i.e., melon [16], watermelon [17,18], and cucumber [19], and those of the Solanaceae family $[20,21]$ have been conducted, but there is relatively few data for eggplant.

The majority of previous studies investigated eggplant and tomato rootstock compatibility with eggplant scion individually. The objective of the present study was to compare the effect of tomato and eggplant rootstocks on fruit yield and certain quality parameters of eggplant cv. 'Madonna' in soilless pot culture in an unheated plastic greenhouse. Moreover, current research is aimed at identifying the best rootstock type to maximize yield and fruit quality, conducting not only laboratory testing, but sensory evaluation as well.

\section{Materials and Methods}

\subsection{Experimental Site, Plant Material, and Management Practices}

The experiment was conducted from March 2019 until October 2019 at the Experimental and Research Farm, Faculty of Horticultural Science, Szent István University, Budapest, in unheated plastic house $\left(47^{\circ} 23^{\prime} 49^{\prime \prime} \mathrm{N}, 19^{\circ} 09^{\prime} 10^{\prime \prime} \mathrm{E}, 120 \mathrm{~m}\right.$ a.s.l.). The study was arranged based on completely randomized design (CRD) to understand the effect of different rootstocks suitable for eggplant grafting, including Solanum grandiflorum $\times$ Solanum melongena (SH), Solanum torvum (ST), Solanum melongena $\times$ Solanum integrifolium (SI), and Solanum integrifolium (A) and tomato rootstocks (Solanum lycopersicum), including cv. 'Optifort' (O) and cv. 'Emperador' (E). Moreover, self-grafted (SG) cv. 'Madonna' and self-rooted (SR) plants, as control, were used with four replications and five plants in each replication.

The used, popular eggplant cultivar 'Madonna' has evenly coloured, dark-violet fruits. Due to slow seed germination, all four eggplant rootstock seeds (SH, A, ST, and SI) were sown 10 days earlier than cv. 'Madonna' and tomato rootstocks seeds (E and O) (which germinated and developed at the same rate); thus, a uniform stem diameter for grafting was obtained. Eggplant seedlings (with the adequate diameter and $4-5$ leaves) were grafted onto the rootstocks by cleft grafting method and kept in high humidity and low light conditions for one week, and then acclimatized to the natural conditions. Three weeks after grafting, all seedlings were transplanted into $10 \mathrm{~L}$ pots containing peat substrate, in an unheated polyethylene greenhouse. Temperature and relative humidity inside the greenhouse were recorded by the Flower Power Sensor data logger, as shown in Figure 1. All phytotechnical work recommended for eggplant greenhouse cultivation was performed uniformly. Irrigation was applied twice a week with a commercial fertilizer solution.

Mature fruits were harvested once a week between June and October 2019 (15 times) according to fruit size, colour, and glossiness. Right after picking, the weight of each fruit was recorded by using a digital scale, and the marketable or unmarketable fruits had been sorted. Fruit width (at maximum fruit diameter) and fruit length (from stalk to end of fruit) had been measured by a tape line, and fruit index was calculated based on fruit width/fruit length. 


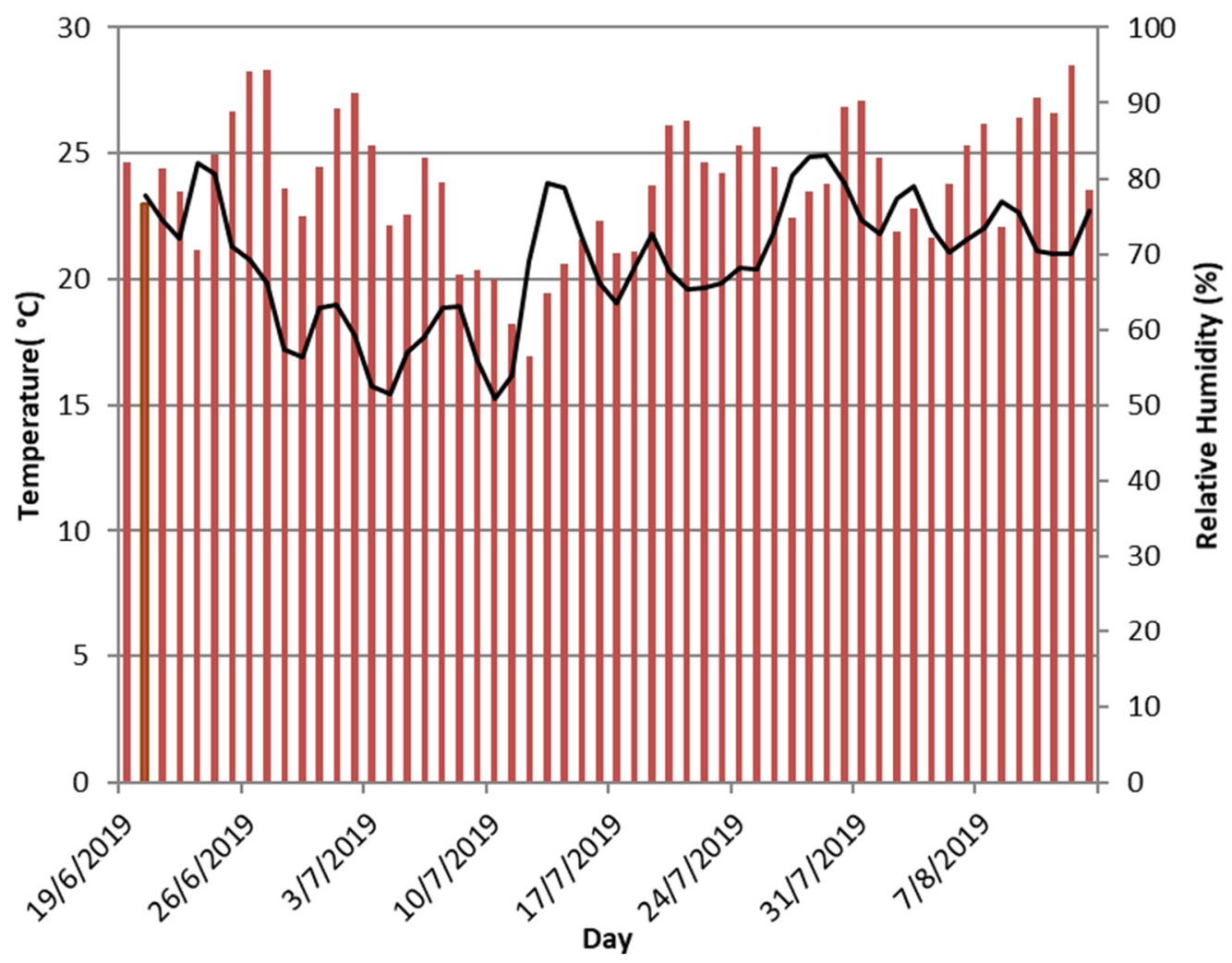

Figure 1. Temperature and relative humidity at the greenhouse during cultivation.

\subsection{Instrumental Measurements}

The fruit flesh acidity $(\mathrm{pH})$ was measured from two sides of each fruit in all combinations by a $\mathrm{pH}$ meter (Hanna HI 98128). The pulp of three fruits from each replication were blended using a kitchen blender. The total soluble solids of the fruit (TSS \%) was measured by using a refractometer (PAL-1 Brix 0-53\% Digital Hand) from the fruit juice. Fruit firmness from each replication (two fruits) were evaluated by a small hand-operated penetrometer. The pressure value was measured in $\mathrm{kg} / \mathrm{cm}^{3}$.

The skin colour of three fruits from each replication was measured on two sides of the skin by using a Minolta Chroma CR-400 colourimeter (Minolta Corporation, Ltd., Osaka, Japan). Fruit chromaticity was expressed in $\mathrm{L}^{*}, \mathrm{a}^{*}, \mathrm{~b}^{*}$ colour space coordinates. Chroma $\left(\mathrm{C}^{*}\right)$ and Hue angles $\left(\mathrm{H}^{\circ}\right)$ were calculated according to the following formula 1 :

$$
\mathrm{C}^{*}=\left(\mathrm{a}^{* 2}+\mathrm{b}^{* 2}\right)^{1 / 2}, \mathrm{H}^{\circ}=\tan ^{-1}\left(\mathrm{~b}^{*} / \mathrm{a}^{*}\right)
$$

The same colourimeter was used to determine the whitening index (DW), oxidation potential (OP), and colour differences (CD) of the fruit pulp. Two fruits of each replication were cut longitudinally with a straight edge plastic knife. The pulp was measured quickly after being cut $\left(\mathrm{L}_{0}\right)$ and after $30 \mathrm{~min}$ $\left(\mathrm{L}_{30}\right)$ in the central and lateral zone. Colour space had been divided into a three-dimensional (L, a and b) so that L (lightness; 0 black and 100 white); a (red to green); and b (blue to yellow). The distance of pure white (DW) was measured as Euclidean distance of the colour coordinates to the pure white coordinates $\left(\mathrm{L}^{*}=100 \mathrm{a}^{*}=0 \mathrm{~b}=0\right)$ using the formula 2 [22]:

$$
\mathrm{DW}=\left((100-\mathrm{L})^{2}+\mathrm{a}^{* 2}+\mathrm{b}^{* 2}\right)^{0.5}
$$


The colour differences (CD) were measured as a Euclidean distance between the colour coordinates at 0 and $30 \mathrm{~min}$ and calculated by using formula 3 :

$$
C D=\left[\left(L^{*} 30-L^{*} 0\right)+\left(a^{* 30}-a^{*} 0\right)+\left(b^{*} 30-b^{*} 0\right)\right]
$$

Moreover, the oxidation potential (OP) was measured by International Commission on Illumination (CIE) $\mathrm{L}^{*} \mathrm{a}^{*} \mathrm{~b}^{*}$ values using the following formula 4 [23]:

$$
\mathrm{OP}=\mathrm{L}_{30}^{*}-\mathrm{L}_{0}^{*}
$$

Ten independent slices from the equatorial region of fruits were cut and incubated at $20{ }^{\circ} \mathrm{C}$ to induce seed browning and facilitate seed boundaries identification. Images were used to determine the number of seeds by using the software ImageJ (Version 1.8.0_172; Research Services Branch, National Institute of Mental Health, Bethesda, MD, USA).

\subsection{Sensory Evaluation}

Sensory measurements were made based on questionnaire results. Twelve trained tasting panellists evaluated 10 quality attributes (Table 1) according to ISO 13,299 standard. First, the sensory attributes and their corresponding reference values were determined, to reduce the variation in the resulting dataset. For the sensory test, small pieces of the fruit were boiled for $20 \mathrm{~min}$, placed in numbered plates, and were immediately assessed. The questionnaire results were converted into a grade scale from 0 to 100. The combined results of the properties were plotted on profile diagrams, which were prepared by ProfiSens, a sensory analysis software. Tests were performed according to ISO 8589, and differences between data were evaluated with univariate ANOVA and Fisher least significant difference (LSD) significance level evaluation procedures.

Table 1. Definitions of sensory attributes used in the quantitative descriptive analysis.

\begin{tabular}{cc}
\hline Attributes & Characteristic \\
\hline Flesh Colour & Dark-light \\
Odour & None-very intensive \\
Flesh Firmness & Soft-firm \\
Flesh Juiciness & not very juicy-very juicy \\
Flavour Intensity & not perceptible-intense \\
Tart, Bitter Taste & None-very intensive \\
Pungent Flavour & None-very intensive \\
Sweet Taste & not very intensive-very intensive \\
After Taste & None-very intensive \\
Off-Flavour & None-very intensive \\
\hline
\end{tabular}

\subsection{Statistical Procedures}

The experiment was arranged in a completely randomized design (CRD) with four replications and five plants in each replication. Data were statistically analysed using Statistix 8 software (Tallahassee, FL, USA). Data were subjected to the one-way analysis of variance (ANOVA) and means were separated using the least significant difference (LSD) test at $p<0.05$.

\section{Results}

As shown in Table 1, grafting cv. 'Madonna' onto 'O and E rootstocks caused the lowest fruit length in comparison with the SR and SG rootstocks. Moreover, it has been observed that self-grafting cv. 'Madonna' significantly increased the width of fruit relative to the fruit harvested from control and other combinations (except ST). Statistical analysis showed that fruit shape index was not significantly $(p<0.05)$ influenced by rootstocks. 
Our results showed that the total marketable fruit number significantly increased by grafting in comparison with SR and SG. Average fruit weight decreased by grafting onto O rootstocks in comparison with other treatment (except SG). Grafting cv. 'Madonna' on eggplant rootstocks (SH, ST, SI, and A) significantly increased total marketable fruit yield while tomato rootstocks (E and O) had no significant effect. Total marketable yield of Solanum toroum (ST) rootstock was two times higher than control, self-grafted plants (Table 2).

Table 2. Effect of different rootstock combinations on eggplant fruit shape, fruit number, and yield.

\begin{tabular}{|c|c|c|c|c|c|c|}
\hline Treatment & $\begin{array}{l}\text { Fruit Length } \\
\text { (cm) }\end{array}$ & $\begin{array}{l}\text { Fruit Width } \\
\quad(\mathrm{cm})\end{array}$ & $\begin{array}{l}\text { Fruit Shape } \\
\text { Index }\end{array}$ & $\begin{array}{l}\text { Total Marketable } \\
\text { Fruit Number } \\
\text { (plant- }{ }^{\mathbf{1}} \text { ) }\end{array}$ & $\begin{array}{l}\text { Average Fruit } \\
\text { Weight (kg) }\end{array}$ & $\begin{array}{l}\text { Total Marketable } \\
\left.\text { Yield (kg plant }{ }^{-1}\right)\end{array}$ \\
\hline SR & $16.97 \mathrm{a}$ & $8.06 \mathrm{bcd}$ & $2.13 \mathrm{a}$ & $6.35 c$ & $0.28 \mathrm{ab}$ & $1.65 \mathrm{c}$ \\
\hline \multicolumn{7}{|c|}{ Eggplant Rootstocks } \\
\hline SG & $18.10 \mathrm{a}$ & $9.38 \mathrm{a}$ & $1.92 \mathrm{a}$ & $6.70 \mathrm{c}$ & $0.26 b c$ & $1.89 \mathrm{c}$ \\
\hline $\mathrm{SH}$ & $16.34 \mathrm{ab}$ & $7.94 \mathrm{~cd}$ & $2.06 \mathrm{a}$ & $12.13 \mathrm{ab}$ & $0.29 \mathrm{ab}$ & $3.36 \mathrm{ab}$ \\
\hline ST & $16.58 \mathrm{a}$ & $8.36 \mathrm{ab}$ & $1.99 \mathrm{a}$ & $14.26 \mathrm{a}$ & $0.28 \mathrm{ab}$ & $3.94 \mathrm{a}$ \\
\hline SI & $16.93 \mathrm{a}$ & $8.18 \mathrm{bc}$ & $2.08 \mathrm{a}$ & $10.80 \mathrm{~b}$ & $0.31 \mathrm{a}$ & $3.23 \mathrm{ab}$ \\
\hline A & $16.91 \mathrm{a}$ & $8.19 \mathrm{bc}$ & $2.07 \mathrm{a}$ & $11.14 \mathrm{~b}$ & $0.29 \mathrm{ab}$ & $3.34 \mathrm{ab}$ \\
\hline \multicolumn{7}{|c|}{ Tomato Rootstocks } \\
\hline E & $15.66 \mathrm{bc}$ & $8.11 \mathrm{bcd}$ & $1.95 \mathrm{a}$ & $10.71 \mathrm{~b}$ & $0.28 \mathrm{ab}$ & $2.80 \mathrm{abc}$ \\
\hline $\mathrm{O}$ & $14.94 \mathrm{c}$ & $7.68 \mathrm{~d}$ & $1.96 \mathrm{a}$ & $9.38 \mathrm{~b}$ & $0.24 \mathrm{c}$ & $2.39 \mathrm{bc}$ \\
\hline $\mathrm{CV}$ & 10.87 & 11.19 & 12.42 & 15.00 & 26.67 & 20.19 \\
\hline$p$ Value & 0.000 & 0.0005 & 0.003 & 0.000 & 0.009 & 0.0002 \\
\hline Significance & $* * *$ & $* * *$ & $* *$ & $* * *$ & $* *$ & $* * *$ \\
\hline
\end{tabular}

According to ANOVA, $\mathrm{L}^{*}$ value and CIRG index (Color index of red) of fruit skin from all combinations was not significantly $(p<0.05)$ different with the self-rooted (SR) plants. Grafting Madonna onto $\mathrm{O}, \mathrm{E}, \mathrm{A}$, and SH significantly increased the $\mathrm{a}^{*}$ value of skin fruit relative to SR and SG (Table 3). Fruit harvested from $\mathrm{O}$ rootstocks had the highest $b^{*}$ value compared with the SR. Our results showed that the highest Hue value was observed at $\mathrm{E}$ and $\mathrm{O}$ rootstock in comparison with SR and SG. Chroma value of skin fruit increased when $\mathrm{O}, \mathrm{E}$, and A was used as rootstock compared with either non-grafted or self-grafted (Table 3).

Table 3. Effect of different rootstock combinations on chromatic characteristics of eggplant fruit skin.

\begin{tabular}{ccccccc}
\hline Treatment & $\mathbf{L}^{*}$ & $\mathbf{a}^{*}$ & $\mathbf{b}^{*}$ & Hue & Chroma & CIRG \\
\hline SR & $25.22 \mathrm{a}$ & $3.09 \mathrm{~d}$ & $-0.72 \mathrm{bc}$ & $3.18 \mathrm{~cd}$ & $346.15 \mathrm{~cd}$ & $6.62 \mathrm{a}$ \\
\hline \multicolumn{7}{c}{ Eggplant Rootstocks } \\
\hline SG & $25.07 \mathrm{a}$ & $2.95 \mathrm{~d}$ & $-0.73 \mathrm{bc}$ & $3.05 \mathrm{~d}$ & $345.13 \mathrm{~d}$ & $6.69 \mathrm{a}$ \\
$\mathrm{SH}$ & $25.36 \mathrm{a}$ & $3.62 \mathrm{abc}$ & $-0.71 \mathrm{bc}$ & $3.70 \mathrm{abc}$ & $347.70 \mathrm{abc}$ & $6.53 \mathrm{a}$ \\
ST & $25.58 \mathrm{a}$ & $3.32 \mathrm{bcd}$ & $-0.75 \mathrm{bc}$ & $3.40 \mathrm{bcd}$ & $346.68 \mathrm{bcd}$ & $6.51 \mathrm{a}$ \\
$\mathrm{SI}$ & $25.08 \mathrm{a}$ & $3.27 \mathrm{~cd}$ & $-0.79 \mathrm{c}$ & $3.72 \mathrm{~cd}$ & $346.03 \mathrm{~cd}$ & $6.65 \mathrm{a}$ \\
\hline $\mathrm{A}$ & $25.61 \mathrm{a}$ & $3.65 \mathrm{abc}$ & $-0.69 \mathrm{ab}$ & $3.71 \mathrm{abc}$ & $348.69 \mathrm{ab}$ & $6.47 \mathrm{a}$ \\
\hline \multicolumn{7}{c}{ Tomato Rootstocks } \\
\hline E & $25.53 \mathrm{a}$ & $3.89 \mathrm{ab}$ & $-0.67 \mathrm{ab}$ & $3.95 \mathrm{ab}$ & $348.92 \mathrm{ab}$ & $6.46 \mathrm{a}$ \\
O & $25.45 \mathrm{a}$ & $4.08 \mathrm{a}$ & $-0.611 \mathrm{a}$ & $4.14 \mathrm{a}$ & $349.51 \mathrm{a}$ & $6.46 \mathrm{a}$ \\
\hline CV & 4.35 & 20.15 & -22.19 & 28.66 \\
$p$ Value & 0.47 & 0.001 & 0.006 & 0.001 & 0.002 & 0.084 \\
Significance & NS & $* * *$ & $* *$ & $*$ & NS \\
\hline
\end{tabular}

NS $=\overline{\text { not significant; }}{ }^{* *}=$ Significant at $p \leq 0.01,{ }^{* * *}=$ Significant at $p \leq 0.001$. Different letters indicate significant difference according to the LSD test $(p<0.05)$. SR = self-root; SG = self-grafting; $\mathrm{SH}=S$. grandiflorum $\times$ S. melongena; $\mathrm{ST}=$ S. torvum $; \mathrm{SI}=$ S. melongena $\times$ S. integrifolium $; \mathrm{A}=$ S. integrifolium $; \mathrm{E}=$ Emperador; $\mathrm{O}=\mathrm{O}$ Optifort. 
The results of pulp colour measurements are presented in Table 4. No significant difference was observed in $\mathrm{L}_{0}^{*}, \mathrm{a}^{*}, \mathrm{CD}$ and $\mathrm{DW}_{0}$ between grafted and SR plants. Moreover, our results showed that grafting onto tomato rootstocks ( $\mathrm{E}$ and $\mathrm{O}$ ) significantly decreased OP value of pulp fruit relative to SR and SG.

Table 4. Effect of different rootstock combinations on chromatic characteristics, colour difference, whiteness degree, and oxidation potential of eggplant pulp.

\begin{tabular}{|c|c|c|c|c|c|c|}
\hline Treatment & $\mathbf{L}_{0}{ }^{*}$ & $a^{*}$ & $\mathbf{b}^{*}$ & CD & $\mathrm{DW}_{0}$ & OP \\
\hline SR & $84.89 \mathrm{ab}$ & $-4.10 \mathrm{ab}$ & $29.08 \mathrm{a}-\mathrm{c}$ & $12.16 \mathrm{a}-\mathrm{c}$ & $33.10 \mathrm{a}-\mathrm{c}$ & $9.97 \mathrm{a}$ \\
\hline \multicolumn{7}{|c|}{ Eggplant Rootstocks } \\
\hline SG & $85.43 \mathrm{ab}$ & $-3.71 \mathrm{ab}$ & $26.84 \mathrm{c}$ & $12.62 \mathrm{ab}$ & $30.85 c$ & $10.66 \mathrm{a}$ \\
\hline $\mathrm{SH}$ & $84.62 \mathrm{ab}$ & $-4.01 \mathrm{ab}$ & $29.15 \mathrm{abc}$ & $13.61 \mathrm{a}$ & $33.24 \mathrm{abc}$ & $8.67 \mathrm{ab}$ \\
\hline ST & $84.03 \mathrm{~b}$ & $-2.86 \mathrm{a}$ & $30.14 \mathrm{ab}$ & $11.46 \mathrm{abc}$ & $34.25 \mathrm{ab}$ & $9.67 \mathrm{ab}$ \\
\hline SI & $85.26 \mathrm{ab}$ & $-4.56 \mathrm{~b}$ & $29.05 \mathrm{abc}$ & $12.48 \mathrm{ab}$ & $32.93 \mathrm{abc}$ & $9.38 \mathrm{ab}$ \\
\hline A & $84.65 \mathrm{ab}$ & $-3.17 \mathrm{ab}$ & $30.32 \mathrm{a}$ & $13.21 \mathrm{a}$ & $34.30 \mathrm{ab}$ & $11.03 \mathrm{a}$ \\
\hline \multicolumn{7}{|c|}{ Tomato Rootstocks } \\
\hline $\mathrm{E}$ & $86.36 \mathrm{a}$ & $-4.71 \mathrm{~b}$ & $27.70 \mathrm{bc}$ & $7.37 \mathrm{c}$ & $31.30 \mathrm{bc}$ & $5.81 \mathrm{~b}$ \\
\hline $\mathrm{O}$ & $83.91 \mathrm{~b}$ & $-3.68 a b$ & $31.39 \mathrm{a}$ & 8.29 bc & $35.51 \mathrm{a}$ & $5.81 \mathrm{~b}$ \\
\hline $\mathrm{CV}$ & 2.71 & -4.82 & 8.88 & 27.58 & 9.25 & 16.90 \\
\hline$p$ value & 0.4 & 0.2 & 0.02 & 0.1 & 0.06 & 0.05 \\
\hline Significance & NS & NS & $*$ & NS & NS & $*$ \\
\hline
\end{tabular}

NS = not significant; ${ }^{*}$ Significant at $p \leq 0.05$. Different letters indicate significant difference according to LSD's test $(p<0.05) . S R=$ self-root; $\mathrm{SG}=$ self-grafting; $\mathrm{SH}=S$. grandiflorum $\times$ S. melongena; $\mathrm{ST}=S$. torvum; $\mathrm{SI}=$ S. melongena $\times$ S. integrifolium; $\mathrm{A}=$ S. integrifolium; $\mathrm{E}=$ Emperador; $\mathrm{O}=$ Optifort. $\mathrm{CD}=$ colour difference; $\mathrm{DW}=$ whiteness degree; $\mathrm{OP}=$ oxidation potential.

As shown in Table 5, Brix value of fruit flesh was negatively influenced by grafting onto SI, E, and $\mathrm{O}$ rootstocks, while SG resulted the highest Brix value in the pulp. Fruit firmness significantly decreased by grafting (except grafting onto $\mathrm{SH}$ rootstock). The $\mathrm{pH}$ value of the flesh was not influenced by different rootstocks.

Table 5. Effect of different rootstock combinations on $\mathrm{pH}$, Brix, firmness, and seed number of eggplant fruits.

\begin{tabular}{|c|c|c|c|c|}
\hline Treatment & $\mathrm{pH}$ & T.S.S (Brix) & Firmness $\left(\mathrm{kg} / \mathrm{cm}^{3}\right)$ & Seed Number \\
\hline SR & $5.55 \mathrm{a}$ & $5.28 \mathrm{~b}$ & $4.93 \mathrm{a}$ & $21.81 \mathrm{c}$ \\
\hline \multicolumn{5}{|c|}{ Eggplant Rootstocks } \\
\hline SG & $5.57 \mathrm{a}$ & $5.80 \mathrm{a}$ & $4.18 \mathrm{~b}$ & $29.50 \mathrm{bc}$ \\
\hline $\mathrm{SH}$ & $5.46 \mathrm{ab}$ & $5.26 \mathrm{~b}$ & $4.56 \mathrm{ab}$ & $47.30 \mathrm{a}$ \\
\hline ST & $5.53 \mathrm{a}$ & $5.34 \mathrm{~b}$ & $3.51 \mathrm{c}$ & $38.70 \mathrm{abc}$ \\
\hline SI & $5.44 \mathrm{ab}$ & $4.78 \mathrm{c}$ & $3.56 c$ & $44.36 \mathrm{ab}$ \\
\hline $\mathrm{A}$ & $5.38 \mathrm{~b}$ & $5.62 \mathrm{ab}$ & $4.04 \mathrm{bc}$ & $25.46 \mathrm{c}$ \\
\hline \multicolumn{5}{|c|}{ Tomato Rootstocks } \\
\hline $\mathrm{E}$ & $5.56 \mathrm{a}$ & $4.62 c$ & $2.77 \mathrm{~d}$ & $27.09 \mathrm{bc}$ \\
\hline $\mathrm{O}$ & $5.53 \mathrm{a}$ & $4.72 \mathrm{c}$ & $2.43 \mathrm{~d}$ & $28.15 \mathrm{bc}$ \\
\hline $\mathrm{CV}$ & 2.45 & 10.59 & 14.42 & 14.03 \\
\hline$p$ Value & 0.06 & 0.000 & 0.000 & 0.000 \\
\hline Significance & NS & $* * *$ & $* * *$ & $* * *$ \\
\hline
\end{tabular}

NS $=$ not significant; ${ }^{* * *}=$ Significant at $p \leq 0.001$. Different letters indicate significant difference according to the $\mathrm{LSD}$ test $(p<0.05) . \mathrm{SR}=$ self-root; $\mathrm{SG}=$ self-grafting; $\mathrm{SH}=$ S. grandiflorum $\times$ S. melongena $; \mathrm{ST}=\mathrm{S}$. torvum; $\mathrm{SI}=\mathrm{S}$. melongena $\times$ S. integrifolium; $\mathrm{A}=$ S. integrifolium $; \mathrm{E}=$ Emperador; $\mathrm{O}=$ Optifort. 
In the current experiment, grafting eggplant onto SH and SI rootstocks sharply increased the seed number of fruits in comparison with SR (Table 4; Figure 2).

Sensory analysis data showed a significant difference in four parameters (flesh colour, firmness, sweet taste, and intensive odour) between selected rootstocks. Fruits harvested from SR, ST, and O had lighter flesh colour than other rootstock combinations. Respectively, SR and E had the lowest and highest flesh firmness between grafting combinations according to panellists' evaluation. Grafting onto ST showed significantly stronger sweet taste as compared to SR fruits. Fruits harvested from SI showed significantly intensive odour among all combinations (Figure 3). Bitter taste, pungent flavour, off flavour, aftertaste, flesh juiciness, and flavour intensity were not significantly influenced by grafting.

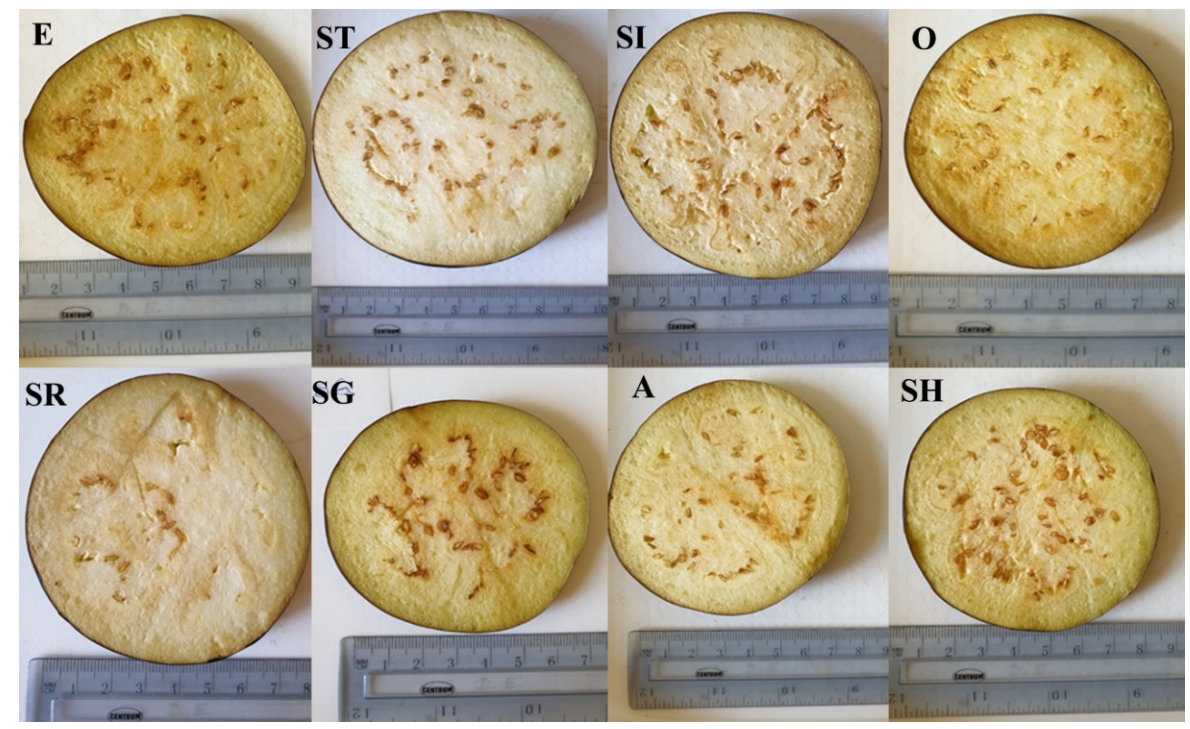

Figure 2. Effect of different rootstock combinations on fruit seed number. SR = self-root; $\mathrm{SG}=$ self-grafting; $\mathrm{SH}=$ S. grandiflorum $\times$ S. melongena $; \mathrm{ST}=$ S. torvum; $\mathrm{SI}=$ S. melongena $\times$ S. integrifolium; $\mathrm{A}=$ S. integrifolium; $\mathrm{E}=$ Emperador; $\mathrm{O}=$ Optifort.

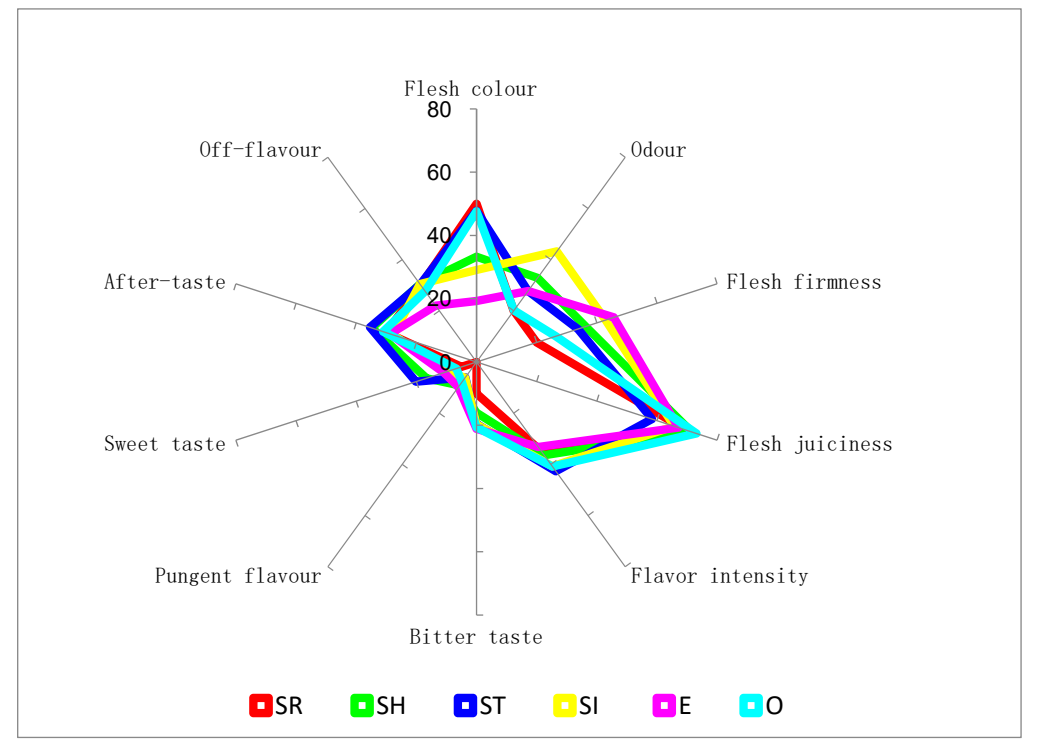

Figure 3. Effect of different rootstock combinations on sensory evaluation of fruit by trained panellists.

\section{Discussion}

Vegetable quality is defined by external attributes, such as colour, shape, size and freshness, as well as internal features, such as texture, flavour, content of mineral, health-promoting compounds, 
and sensory parameters. The quality of grafted vegetables can differ and conflicting from the grower and consumer perspectives. However, consumer demand determines economic value and it is an essential aspect in grafted vegetable productions. In the current experiment, we have tested the 'Madonna' eggplant cultivar grafted onto two groups of rootstocks (tomato and other Solanum spp.) to find the best combination in terms of yield and quality in both laboratory and consumer evaluation.

Our results showed that the lowest fruit length was observed at tomato rootstock (E and O) and highest fruit width was at SG rootstocks. Fruit shape is controlled genetically; however, Sabatino et al. [6,24] and Gisbert et al. [25] demonstrated that eggplant fruit shape (length and width) is affected by the rootstock. In line with our findings, Passam et al. [26] stated that grafting can increase eggplant fruit size. Moreover, Cassaniti et al. [27] harvested longer fruits from cv. 'Black Bell' - S. torvum combination than from self-grafted plants. In cucumber, shape index in grafted plants was higher than non-grafted ones [28], while in watermelon grafting it had no influence on fruit size and shape, according to some studies [29,30]. Therefore, these results are different due to genotype, vigorous rootstocks, and grafting combinations [3]. For instance, grafting tomato onto vigorous rootstocks (i.e., 'Maxifort'; 'Beaufort') increased the fruit size, while grafting onto less vigorous rootstocks (i.e., 'Brigeor'; 'Energy,'; 'Firefly', 'Linea9243,' and 'Nico') reduced tomato fruit size [31-33].

All eggplant rootstocks (SH, ST, A, and SI) improved total fruit yield. Yield, fruit number, and earliness of eggplant $\mathrm{cv}$. 'Cristal F1' grafted onto eggplant rootstocks was higher than tomato rootstocks [25]. In line with our results, Sabatino et al. [19] reported that eggplant cv. 'Scarlatti' F1 grafted onto $S$. melongena $\times$ S. aethiopicum rootstock had higher total and marketable yield than plants grafted onto S. aethiopicum. Earlier, they found that higher marketable yield of grafted eggplant onto S. torvum and S. macrocarpon can be the result of higher fruit numbers, which associate with increasing water and nutrient absorption [6]. Gisbert et al. [25] confirmed that grafted plants with higher yield had earlier fruit harvesting. In the current experiment, the higher marketable yield is due to a higher harvested fruit number in grafted plants. Our results also correlate with Sabatino et al. [5] who confirmed a higher fruit number of grafted plants than on non-grafted. Higher yield of grafted plants may be related to higher water and nutrient absorption [29].

The darkest skin colour is connected to a high concentration of anthocyanin. Results of Moncada et al. [34] showed that grafting eggplant cv. 'Biragh' onto S. torvum caused a darker and less vivid fruit skin colour (lower value of L* and chroma), while other cultivars ('Black Moon' and 'Black Bell') were not influenced by rootstock. Moreover, the highest Hue value was observed when eggplant cv. 'Scarlatti' was grafted onto S. torvum and S. aethiopicum rootstocks in an experiment by Sabatino et al. [24]. In our study, the most noticeable finding was that grafting cv. 'Madonna' onto O rootstock resulted in low-quality fruit skin, with the Hue value of 4.14, and chroma of 349.51. In tomato, variable results were found in fruit skin colour by grafted plants compared to non-grafted ones [31,35].

A CIRG index of 5 indicates red dark violet skin, and higher than 6 indicates blue-black skin. In the current experiment, 'Madonna' scion normally had dark black skin and grafting did not have any significant influence on CIRG. Kacjan Maršic et al. [13] reported that grafting eggplant cv. 'Blackbell' onto tomato rootstock cv. 'Beaufort' increased CIRG index, while in another cultivar (cv. 'Epic') decreased. It can be explained that scion variety has different responses to grafting according to Kacjan Maršic et al. [13]. Moreover, they concluded that higher vigour of grafted plants negatively influenced the anthocyanins, and the pruning of plants should be carried out during the cultivation to improve the fruit colour [13].

It seems that tomato rootstocks had lower browning degree and colour difference value than self-rooted and self-grafted plants, and fruit harvested from these combinations oxidized less than others (Table 3). High oxidation potential is expected due to the high phenolic compound content of the eggplant. Moreover, it may be influenced by many factors, e.g., scion genotype, rootstocks, and environmental conditions. Moncada et al. [34] and Sabatino et al. [6] reported that grafting eggplant onto S. torvum had little or no effect on pulp browning. However, other rootstocks had different reactions; for instance, S. paniculatum and S. macrocarpon showed lowest [6], while S. aethiopicum gave 
the highest oxidation potential in eggplant [3]. Seed number and fruit size may lead to different colour and oxidization in fruit pulp after cutting. A negative correlation between the browning index and fruit size, and positive relation with seed number, has been reported by Radicetti et al. [36].

Several studies confirmed that fruit quality seldom varied significantly between grafted and non-grafted plants. For instance, previous results by Arvanitoyannis et al. [37] and Cassaniti et al. [27] confirmed a reduction in eggplant flesh firmness by grafting. Similarly, tomato fruits harvested from grafted plants were not firmer than control and self-grafted plants [31,38]. Lower water uptake in non-grafted plant caused lower water content in eggplant fruit and harder texture [37]. The current experiment showed that grafting significantly reduced TSS of eggplant cv. 'Madonna'. In line with our results, lower TSS was observed in eggplant fruits (cv. 'Faselis') obtained from grafted on S. torvum, while no significant difference was found in fruits (cv. 'Rima') obtained from tomato hybrid rootstocks compared to the rest of combinations [39]. Lee et al. [40] reported that grafting eggplant onto S. torvum had no influence on TSS. Previous studies showed that firmness and SSC of non-grafted and self-grafted melon was higher than grafted fruit in the Guan et al. [14] study, and they explained that it is due to the improved water status of grafted melon by enhancing leaf water potential, leaf stomatal conductance, transpiration rate, and amount of xylem sap, which then can reduce TSS of the fruit [14,41]. Fruits obtained from SH and SI × 'Madonna' combination had the highest seed number and it can be explained that higher nitrogen absorption in the grafted plant may cause a higher seed number in fruit [42].

Combining sensory and instrumental measurements provided a thorough evaluation of the effects of grafting and rootstock combination [14]. Grafting eggplant cv. 'Tsakoniki' onto S. torvum resulted in fewer empty spaces and harder fruits more than in case of other combinations [37]. Moreover, they reported that fruits grafted on S. sisymbriifolium had fewer seeds and less intensive tart flavour than the rest of the treatments. Another interesting finding was that all grafted plants resulted in less sweet fruits and lower acceptability ratings in the panellist test [37]. In our experiment, fruit harvested from ST had a sweeter taste and lighter colour, and fruit harvested from SI showed intensive odour, according to consumer evaluation. In tomato, according to the experiment of Di Gioia et al. [20], grafting onto cv. 'Beaufort' and 'Maxifort' rootstocks did not influence sweetness, sourness, and the tomato-like taste of the fruits. Barrett et al. [21] and Casals et al. [43] reported that grafting had negative effects on acceptability and the tomato flavour descriptors assessed by a consumer test.

In the Cucurbitaceae family, Guan et al. [14] reported that grafting Galia melon onto hybrid squash rootstocks caused lower sensory properties, while Honey Yellow cv. was not influenced by grafting. They explained that lower SSC can be one of the reasons of the lower sensory evaluation results. Similarly, in another experiment, Velkov and Pevicharova [19] confirmed that sensory evaluation of cucumber depended on scion-rootstock combinations and every scion showed a different reaction to the same rootstock.

\section{Conclusions}

In the present study, we examined the effect of grafting onto different rootstocks in case of an eggplant variety favoured by consumers. Either tomato or other Solanum species are recommended for the grafting of eggplant; thus, we also selected the rootstocks to be tested accordingly. Compared to previous studies, we also observed differences between each grafting combination, both in terms of yield and fruit quality.

In our study, Solanum torvum $\times$ Madonna, as well as Solanum grandiflorum $\times$ Solanum melongena $\times$ Madonna combinations, exhibited the highest marketable yield with a higher fruit number per plant and uniform skin colour. Our findings also revealed that tomato rootstocks ( $\mathrm{O}$ and $\mathrm{E})$ had the lowest pulp colour difference and oxidation potential.

Our results also confirm that it is very important to choose the right rootstock, primarily according to the goal of grafting to be achieved. 
Author Contributions: All authors contributed to this research. The design of the experiment was done by N.K., M.M., and N.S.B.I.; M.M. and N.S.B.I. did the recording and processing of the data, as well as the result of the evaluation. The manuscript was written by M.M.; N.K. assisted in writing the paper. N.K. contributed to designing the research and revised the manuscript. The work presented in the paper was conceived within research projects led by N.K. All authors have read and agreed to the published version of the manuscript.

Funding: This research was funded by the Ministry for Innovation and Technology within the framework of the Higher Education Institutional Excellence Program (NKFIH-1159-6/2019) in the scope of plant breeding and plant protection research of Szent István University.

Acknowledgments: This publication was founded by EFOP-3.6.1-16-2016-00016. The specialize of the SZIE Campus of Szarvas research and training profile with intelligent specialization in the themes of water management, hydroculture, precision mechanical engineering, alternative crop production.

Conflicts of Interest: The authors declare no conflict of interest.

\section{References}

1. Mozafarian, M.; Kappel, N. The Role of Grafting Vegetable Crops for Reducing Biotic and Abiotic Stresses. In Handbook of Plant and Crop Stress, 4th ed.; Pessarakli, M., Ed.; CRC Press: Boca Raton, FL, USA, 2019; pp. 855-863. [CrossRef]

2. Mozafarian, M.; Kappel, N. Grafting Plants to Improve Abiotic Stress Tolerance. In Plant Ecophysiology and Adaptation under Climate Change: Mechanisms and Perspectives II; Hasanuzzaman, M., Ed.; Springer: Singapore, 2020; pp. 477-490. [CrossRef]

3. Kyriacou, M.C.; Rouphael, Y.; Colla, G.; Zrenner, R.; Schwarz, D. Vegetable grafting: The implications of a growing agronomic imperative for vegetable fruit quality and nutritive value. Front. Plant Sci. 2017, 8, 1-23. [CrossRef] [PubMed]

4. Boyaci, H.F.; Ellialtioglu, S.S. Rootstock usage in eggplant: Actual situation and recent advances. Acta Hortic. 2020, 1271, 403-410. [CrossRef]

5. Sabatino, L.; Iapichino, G.; Maggio, A.; D’Anna, E.; Bruno, M.; D’Anna, F. Grafting affects yield and phenolic profile of Solanum melongena L. landraces. J. Integr. Agric. 2016, 15, 1017-1024. [CrossRef]

6. Sabatino, L.; Iapichino, G.; D'Anna, F.; Palazzolo, E.; Mennella, G.; Rotino, G.L. Hybrids and allied species as potential rootstocks for eggplant: Effect of grafting on vigour, yield and overall fruit quality traits. Sci. Hortic. 2018, 228, 81-90. [CrossRef]

7. Pebriana, E.; Dawam Maghfoer, M.O.C.H.; Widaryanto, E. Effect of grafting using wild eggplant as rootstock on growth and yield of four eggplant (Solanum melongena L.) cultivars. Biosci. Res. 2018, 15, 337-347.

8. Giuffrida, F.; Cassaniti, C.; Agnello, M.; Leonardi, C. Growth and ionic concentration of eggplant as influenced by rootstocks under saline conditions. Acta Hortic. 2015, 1086, 161-166. [CrossRef]

9. Daunay, M.C. Eggplant. In Handbook of Plant Breeding; Prohens, J., Nuez, F., Eds.; Vegetables II; Springer: New York, NY, USA, 2008; pp. 163-220. [CrossRef]

10. Furini, A.; Wunder, J. Analysis of eggplant (Solanum melongena) related germplasm: Morphological and AFLP data contribute to phylogenetic interpretations and germplasm utilization. Theor. Appl. Genet 2004, 108, 197-208. [CrossRef]

11. Rahman, M.A.; Rashid, M.A.; Hossain, M.M.; Salam, M.A.; Masum, A.S.M.H. Grafting compatibility of cultivated eggplant varieties with wild Solanum species. Pak. J. Biol. Sci. 2002, 5, 755-757. [CrossRef]

12. King, S.R.; Davis, A.R.; Zhang, X.; Crosby, K. Genetics, breeding and selection of rootstocks for Solanaceae and Cucurbitaceae. Sci. Hort. 2010, 127, 106-111. [CrossRef]

13. Kacjan Maršić, N.; Mikulič-Petkovšek, M.; Stampar, F. Grafting influences phenolic profile and carpometric traits of fruits of greenhouse-grown eggplant (Solanum melongena L.). J. Agric. Food Chem. 2014, 62, 10504-10514. [CrossRef]

14. Guan, W.; Zhao, X.; Huber, D.J.; Sims, C.A. Instrumental and sensory analyses of quality attributes of grafted specialty melons. J. Sci. Food Agric. 2015, 95, 2989-2995. [CrossRef] [PubMed]

15. Grieneisen, M.L.; Aegerter, B.J.; Scott Stoddard, C.; Zhang, M. Yield and fruit quality of grafted tomatoes, and their potential for soil fumigant use reduction. A meta-analysis. Agron. Sustain. Dev. 2018, 38, 29. [CrossRef]

16. Németh, D.; Balázs, G.; Daood, H.; Kovács, Z.; Bodor, Z.; Zinia Zaukuu, J.-L.; Szentpéteri, V.; Kókai, Z.; Kappel, N. Standard Analytical Methods, Sensory Evaluation, NIRS and Electronic Tongue for Sensing Taste Attributes of Different Melon Varieties. Sensors 2019, 19, 5010. [CrossRef] 
17. Fekete, D.; Balázs, G.; Bőhm, V.; Várvölgyi, E.; Kappel, N. Sensory evaluation and electronic tongue for sensing grafted and non-grafted watermelon taste attributes. Acta Alimentaria 2018, 47, 487-494. [CrossRef]

18. Liu, Q.; Zhao, X.; Brecht, J.K.; Sims, C.A.; Sanchez, T.; Dufault, N.S. Fruit quality of seedless watermelon grafted onto squash rootstocks under different production systems. J. Sci. Food Agric. 2017, 97, 4704-4711. [CrossRef]

19. Velkov, N.; Pevivharova, G. Effects of cucumber grafting on yield and fruit sensory characteristics. Zemdirbyste Agric. 2016, 103, 405-410. [CrossRef]

20. Di Gioia, F.; Serio, F.; Buttaro, D.; Ayala, O.; Santamaria, P. Influence of rootstock on vegetative growth, fruit yield and quality in 'Cuore di Bue', an heirloom tomato. J. Hort. Sci. Biotechnol. 2010, 854, 77-482. [CrossRef]

21. Barrett, C.E.; Zhao, X.; Hodges, A.W. Cost benefit analysis of using grafted transplants for root-knot nematode management in organic heirloom tomato production. HortTechnology 2012, 22, 252-257. [CrossRef]

22. Larrigaudiere, C.; Lentheric, I.; Vendrell, M. Relationship between enzymatic browning and internal disorders in controlled atmosphere stored pears. J. Sci. Food Agric. 1998, 78, 232-236. [CrossRef]

23. Prohens, J.; Rodriguez-Burruezo, A.; Raigon, M.D.; Nuez, F. Total phenolics concentration and browning susceptibility in a collection of different varietal types and hybrids of eggplant: Implications for breeding for higher nutritional quality and reduced browning. J. Am. Soc. Hort. Sci. 2007, 132, 638-646. [CrossRef]

24. Sabatino, L.; D’Anna, F.; D’Anna, F.; Iapichino, G.; Moncada, A.; D’Anna, E.; De Pasquale, C. Interactive effects of genotype and molybdenum supply on yield and overall fruit quality of tomato. Front. Plant Sci. 2019, 9, 19-22. [CrossRef] [PubMed]

25. Gisbert, C.; Prohens, J.; Raigón, M.D.; Stommel, J.R.; Nuez, F. Eggplant relatives as sources of variation for developing new rootstocks: Effects of grafting on eggplant yield and fruit apparent quality and composition. Sci. Hortic. 2011, 128, 14-22. [CrossRef]

26. Passam, H.C.; Stylianou, M.; Kotsiras, A. Performance of eggplant grafted on tomato and eggplant rootstocks. Eur. J. Hort. Sci. 2005, 70, 130-134.

27. Cassaniti, C.; Giuffrida, F.; Scuderi, D.; Leonardi, C. Effect of rootstock and nutrient solution concentration on eggplant grown in a soilless system. J. Food Agric. Environ. 2011, 9, 252-256.

28. Colla, G.; Rouphael, Y.; Jawad, R.; Kumar, P.; Rea, E.; Cardarelli, M. The effectiveness of grafting to improve $\mathrm{NaCl}$ and $\mathrm{CaCl}_{2}$ tolerance in cucumber. Sci. Hortic. 2013, 164, 380-391. [CrossRef]

29. Colla, G.; Rouphael, Y.; Cardarelli, M.; Rea, E. Effect of salinity on yield, fruit quality, leaf gas exchange, and mineral composition of grafted watermelon plants. HortScience 2006, 41, 622-627. [CrossRef]

30. Soteriou, G.A.; Kyriacou, M.C. Rootstock mediated effects on watermelon field performance and fruit quality characteristics. Intern. J. Vegetable. Sci. 2014, 21, 344-362. [CrossRef]

31. Schwarz, D.; Öztekin, G.B.; Tüzel, Y.; Brückner, B.; Krumbein, A. Rootstocks can enhance tomato growth and quality characteristics at low potassium supply. Sci. Hortic. 2013, 149, 70-79. [CrossRef]

32. Turhan, A.; Ozmen, N.; Serbeci, M.S.; Seniz, V. Effects of grafting on different rootstocks on tomato fruit yield and quality. Hortic. Sci. 2011, 38, 142-149. [CrossRef]

33. Romano, D.; Paratore, A.; Vindigni, G. Caratteristiche dei fruttidi pomodoro in rapporto a diversi portinnesti. In Proceedings of the Workshop on 'Applicazione di Tecnologie Innovative per il Miglioramentodell' Orticoltura Meridionale', Consiglio Nazionale delle Ricerche, Rome, Italy, 18 July 2000; pp. 113-114.

34. Moncada, A.; Miceli, A.; Vetrano, F.; Mineo, V.; Planeta, D.; D'Anna, F. Effect of grafting on yield and quality of eggplant (Solanum melongena L.). Sci. Hortic. 2013, 149, 108-114. [CrossRef]

35. Ulukapi, K.; Onus, A.N. Comparison of the productivity and quality of the grafted and ungrafted tomato plants grown in the greenhouse with mycorrhiza application. X Int. Symp. Process. Tomato 2007. [CrossRef]

36. Radicetti, E.; Massantini, R.; Campigliaa, E.; Mancinelli, R.; Ferri, S.; Moscetti, R. Yield and quality of eggplant (Solanum melongena L.) as affected by cover crop species and residues. Sci. Hortic. 2016, 204, 161-171. [CrossRef]

37. Arvanitoyannis, I.S.; Khah, E.; Christakou, E.C.; Bletsos, F.A. Effect of grafting and modified atmosphere packaging on eggplant quality parameters during storage. Int. J. Food Sci. Tech. 2005, 40, 311-322. [CrossRef]

38. Khah, E.M.; Kakava, E.; Mavromatis, A.; Chachalis, D.; Goulas, C. Effect of grafting on growth and yield of tomato (Lycopersicon esculentum Mill.) in greenhouse and open-field. J. Appl. Hortic. 2006, 8, 3-7. [CrossRef]

39. Khah, E.M. Effect of grafting on growth, performance and yield of aubergine (Solanum melongena L.) in greenhouse and open-field. Intern. J. Plant Prod. 2011, 5, 359-366. [CrossRef] 
40. Lee, J.M.; Kubota, C.; Tsao, S.J.; Biel, Z.; Hoyos Echevaria, P.; Morra, L. Current status of vegetable grafting: Diffusion, grafting techniques, automation. Sci. Hortic. 2010, 127, 93-105. [CrossRef]

41. Rouphael, Y.; Schwarz, D.; Krumbein, A.; Colla, G. Impact of grafting on product quality of fruit vegetables. Sci. Hortic. 2010, 127, 172-179. [CrossRef]

42. Akanbi, W.B.; Togun, A.O.; Olaniran, O.A.; Akinfasoye, J.O.; Tairu, F.M. Physico-chemical properties of eggplant (Solanum melongena L.) fruit in response to nitrogen fertilizer and fruit size. Agric. J. 2007, 2, 140-148.

43. Casals, J.; Rull, A.; Bernal, M.; González, R.; del Castillo, R.R.; Simó, J. Impact of grafting on sensory profile of tomato landraces in conventional and organic management systems. Hortic. Environ. Biotech. 2018, 59, 597-696. [CrossRef]

(C) 2020 by the authors. Licensee MDPI, Basel, Switzerland. This article is an open access article distributed under the terms and conditions of the Creative Commons Attribution (CC BY) license (http://creativecommons.org/licenses/by/4.0/). 